\title{
Dissociative experiences are related to commissions in emotional memory
}

Citation for published version (APA):

Candel, I. E. L., Merckelbach, H. L. G. J., \& Kuijpers, M. (2003). Dissociative experiences are related to commissions in emotional memory. Behaviour Research and Therapy, 41, 719-725. https://doi.org/10.1016/S0005-7967(03)00016-0

Document status and date:

Published: 01/01/2003

DOI:

10.1016/S0005-7967(03)00016-0

Document Version:

Publisher's PDF, also known as Version of record

\section{Please check the document version of this publication:}

- A submitted manuscript is the version of the article upon submission and before peer-review. There can be important differences between the submitted version and the official published version of record.

People interested in the research are advised to contact the author for the final version of the publication, or visit the DOI to the publisher's website.

- The final author version and the galley proof are versions of the publication after peer review.

- The final published version features the final layout of the paper including the volume, issue and page numbers.

Link to publication

\footnotetext{
General rights rights.

- You may freely distribute the URL identifying the publication in the public portal. please follow below link for the End User Agreement:

www.umlib.nl/taverne-license

Take down policy

If you believe that this document breaches copyright please contact us at:

repository@maastrichtuniversity.nl

providing details and we will investigate your claim.
}

Copyright and moral rights for the publications made accessible in the public portal are retained by the authors and/or other copyright owners and it is a condition of accessing publications that users recognise and abide by the legal requirements associated with these

- Users may download and print one copy of any publication from the public portal for the purpose of private study or research.

- You may not further distribute the material or use it for any profit-making activity or commercial gain

If the publication is distributed under the terms of Article $25 \mathrm{fa}$ of the Dutch Copyright Act, indicated by the "Taverne" license above, 


\title{
BEHAVIOUR
}

RESEARCH AND

THERAPY

\section{Dissociative experiences are related to commissions in emotional memory}

\author{
I. Candel *, H. Merckelbach, M. Kuijpers \\ Department of Experimental Psychology, Maastricht University. P.O. Box 616.6200 MD. Maastricht, \\ The Netherlands
}

Received 2 September 2002; received in revised form 3 December 2002; accepted 12 December 2002

\begin{abstract}
Two rival hypotheses of the link between dissociative experiences and emotional memory were tested: 1) the defence mechanism hypothesis that assumes that dissociation promotes fragmentation of emotional memory; and 2) the fantasy proneness hypothesis that claims that because of its overlap with fantasy proneness, dissociation is related to commissions in emotional memory. Undergraduates scoring high ( $n$ $=19)$ or low $(n=19)$ on the Dissociative Experiences Scale (DES) listened to an aversive story. Next, a free recall task was administered. While high dissociators made more commission errors in their free recall than did low dissociators, fantasy proneness did not account for this difference.

(c) 2003 Elsevier Science Ltd. All rights reserved.
\end{abstract}

Keywords: Memory; Emotion; Dissociation; Fantasy proneness

\section{Introduction}

Dissociation refers to a lack of normal integration of thoughts, feelings, and experiences into the stream of consciousness and memory (Bernstein \& Putnam, 1986). Over the past few years, etiological antecedents of dissociative symptoms and experiences have been the object of numerous studies (see for reviews, Gershuny \& Thayer, 1999; Merckelbach \& Muris, 2001). A recurrent theme in these studies is that dissociative symptoms originate from exposure to traumatic events (e.g., Van der Kolk \& Van der Hart, 1989; Gershuny \& Thayer, 1999). According to this traumadissociation view, dissociation would serve as a coping mechanism resulting in a reduced impact of the traumatic event. Many clinicians seem to share this view. For example, Apitzsch (1996;

\footnotetext{
* Comesponding author. Tel.: +31-43-388-1905; fax: +31-43-388-4196.

E-mail address: i.candel@psychology.unimaas.nl (I. Candel).
} 
p. 334) opines that "dissociation at the moment of trauma is highly adaptive. It serves to defend self-consciousness from being contaminated by overwhelming pain, humiliation, and feelings of helplessness".

Another prominent aspect of the trauma-dissociation view is the idea that repeated traumatization may lead to more or less chronic dissociative symptoms that have trait-like qualities (e.g., Loewenstein, 1991). The standard measure for assessing such trait-like dissociation is the Dissociative Experience Scale (DES; Bernstein \& Putnam, 1986). The DES is a self-report scale that asks respondents to indicate on $100-\mathrm{mm}$ visual analog scales (anchors: $0=$ not at all; $100=$ very much) the frequency with which they experience 28 dissociative phenomena (e.g., "Some people have the experience of finding themselves in a place and having no idea how they got there. Please mark the line to show what percentage of the time this happens to you"). Scores are then averaged across items to obtain a mean DES score.

Advocates of the trauma-dissociation view argue that people who have learned to cope with trauma by dissociating are vulnerable to continue to do so in response to minor stressors. As a result, emotional experiences would not integrate into a coherent narrative and would be difficult to retrieve. Little experimental work on the defensive function of dissociation has been done. One notable exception is the study by Holtgraves and Stockdale (1997). These authors showed that individuals with high DES scores recall less emotionally charged words than do individuals with low DES scores. However, this finding was obtained with a word list paradigm that may have little relevance to autobiographical memory.

Alternative interpretations of the origins and consequences of dissociative experiences deserve serious consideration. For example, one clearly established individual difference correlate of dissociation is fantasy proneness (e.g., Rauschenberg \& Lynn, 1995; Merckelbach, Muris, \& Rassin, 1999). Fantasy proneness refers to a deep involvement in fantasy and imagination (Wilson \& Barber, 1983). For college students' samples, correlations between dissociation and fantasy proneness range from 0.42 (Silva \& Kirsch, 1992) to 0.63 (Merckelbach, Muris \& Rassin, 1999). Likewise, Pekala et al. (1999/2000) found a correlation of 0.41 between DES scores and fantasy proneness levels in a sample of substance abuse patients. An approach emphasizing the substantial overlap between fantasy proneness and dissociation leads to completely different predictions as to how dissociative individuals will react to emotionally provocative material. For example, fantasy proneness has been found to be implicated in memory commissions (e.g., Merckelbach, Muris, Rassin, \& Horselenberg, 2000). With this in mind, one would expect that high dissociative individuals display commission rather than omission errors when they retrieve emotional memories. Interestingly, experimental studies relying on a variety of paradigms (e.g., imagination inflation, the Deese-Roediger-McDermott word list paradigm, reality monitoring tasks) found evidence that dissociative experiences are, indeed, related to memory commissions (e.g., Clancy, Schacter, McNally, \& Pitman, 2000; Heaps \& Nash, 1999; Porter, Birt, Yuille, \& Lehman, 2000; Winograd, Peluso, \& Glover, 1998).

The current study further explored the link between dissociative experiences and emotional memory. Undergraduates who scored high or low on the DES were exposed to an emotionally provocative story. Next, participants underwent a free recall task. If dissociation would have defensive qualities, one would predict a raised frequency of memory omissions in high DES individuals as compared to low DES individuals. Alternatively, to the extent that dissociation can be accounted for by fantasy proneness, one would predict more memory commissions in high DES individuals than in low DES individuals. 


\section{Method}

\subsection{Participants}

Participants were 38 Maastricht University undergraduates (29 women). Their mean age was 22 years $(S D=1.94$; range: $18-27$ years). On the base of DES scores obtained in an unrelated experiment we selected individuals with high DES scores exceeding the clinical cut-off of 30 (Ross, Joshi, \& Currie, 1991; high DES group; $n=19$ ) and individuals having a DES score below 6 (low DES group; $n=19$ ). Mean DES scores of the high and low DES group were 36.71 $(S D=5.73)$ and $3.09(S D=1.29)$, respectively $[t(36)=-24.93 ; p<0.001]$. Groups did not differ with regard to age $[t(36)=1.54 ; p=0.13]$. Participants were tested individually.

\subsection{Materials}

As part of a filler task, participants completed the Creative Experience Questionnaire (CEQ: Merckelbach, Horselenberg, \& Muris, 2001). The CEQ (Cronbach alpha $=0.73$ ) is a 25-item selfreport instrument. An illustrative item is: "Many of my fantasies have a realistic intensity". Items are scaled in the true/false form. The number of yes-answers is summed to yield a total CEQ score, with higher scores indicating higher levels of fantasy proneness. There is solid evidence for the reliability and validity of the CEQ (Merckelbach, Horselenberg \& Muris, 2001). Mean scores on the CEQ were $7.58(S D=2.57)$ for the high DES group and $4.37(S D=3.61)$ for the low DES group $[t(36)=-3.16 ; p<0.01]$.

Participants listened to a tape-recorded emotional story (female voice), taken from Wenzlaff, Wegner and Roper (1988). The story is about a student who causes a severe motor vehicle accident while (s)he is on his (her) way to a job interview. The story ends with a description of the victims, a mother and her baby. Participants were asked to identify with the main character of the story (i.e., the student who is responsible for the accident). Previous research in our lab indicated that participants find the story upsetting (Muris, Merckelbach, Van den Hout, \& De Jong, 1992). In order to increase the emotional impact of the story, we added sounds to the story (e.g., breaking glass, scream).

\subsection{Procedure}

Participants were asked to rate their mood on a $100-\mathrm{mm}$ visual analogue scale (VAS; $0=$ very depressed, $100=$ very cheerful). Next, the story was presented. Participants were instructed to imagine they were the main character of the story. The 5 min filler task consisted of $100-\mathrm{mm}$ visual analog scale's asking for mood ratings $(0=$ very depressed; $100=$ very cheerful $)$ and for subjective ratings of the impact of the story $(0=$ not upsetting at all; $100=$ very upsetting), and of the CEQ. Finally, participants completed a free recall task. They were asked to write down the story as accurate and detailed as possible. 


\section{Results}

\subsection{Manipulation checks}

Before they had heard the story, participants gave more positive mood ratings than after they had heard the story, means being $69.47(S D=13.32)$ and $64.74(S D=13.55)$, respectively [ $t(37)=32.16 ; p<0.001]$. Mean rating of the impact of the story was $56.76(S D=20.39)$. This score is similar to that reported by Muris, Merckelbach, Van den Hout and De Jong (1992). High and low DES individuals did not differ with regard to their subjective impact ratings $[t(36)<1]$.

\subsection{Memory performance}

Two judges scored free recall in terms of hits (i.e., number of correctly reproduced elements of the story; maximum score $=38$ ), distortions, and commission errors. A distortion is a major change in the details of an existing element of the original narrative (e.g., "a red Volkswagen" in stead of "a green Volkswagen"), while a commission error refers to the introduction of an entirely novel element (see Gudjonsson \& Clare, 1995). Only if there was agreement between the two judges, scores were assigned to one of the three categories. Percentage of omissions was calculated as number of omitted elements [i.e., 38-(hits + distortions)] divided by 38. Percentage of commissions was defined as number of commissions divided by total free recall output (i.e., hits, distortions and commissions). Independent and Bonnferoni-corrected $t$-tests (adjusted significance levels of $p<0.01$ ) indicated that both groups did not differ with respect to mean percentage hits, means being $47.64(S D=11.06)$ and $43.63(S D=12.42)$ for the high and low DES group, respectively $[t(36)=-1.05 ; p=0.30]$. Similarly, both groups did not differ with respect to mean percentage omissions, means being $51.39(S D=10.24)$ and $55.69(S D=11.87)$ for the high and low DES group, respectively $[t(36)=1.19 ; p=0.24]$. Moreover, percentage distortions did not differ between the groups, means being $2.17(S D=3.43)$ and $2.03(S D=$ 4.35 ) for the high and low DES group, respectively $[t(36)=-0.11 ; p=0.91]$. Mean percentage commissions were 2.9. This fits well with Dunning and Stern's (1992) finding that, in general, commissions account for less than $10 \%$ of the total free recall output. However, the high DES group made more commissions than the low DES group, means being $4.70 \%(S D=5.43)$ and $1.02 \%(S D=2.08)$, respectively $[t(36)=-2.75 ; p<0.01]$. To examine whether the difference in commission errors between both groups was carried by fantasy proneness, we conducted an Analysis of Variance (ANOVA) with group as independent factor, percentage commission errors as dependent variable, and fantasy proneness as covariate. This analysis showed that the difference in percentage commission errors remained significant when the influence of fantasy proneness was corrected for $[F<1]$.

\section{Discussion}

The current study tested the defensive qualities of dissociation and its results can be summarized as follows. To begin with, in contrast to what one would anticipate on the basis of the defenceinterpretation, high and low dissociators did not differ with regard to their rates of memory omis- 
sions. Second, we found that high dissociators produced more commissions in emotional memory than low dissociators. Thirdly, in line with many other studies, participants who scored high on dissociation were also found to have raised fantasy proneness levels as compared to those low on dissociation. However, the group difference in commission errors was not mediated by fantasy proneness, a finding that is in contrast to what one would anticipate on the basis of a fantasy proneness interpretation of dissociation.

High DES individuals did not show more omission errors in free recall than did low DES individuals. This is clearly at variance with the defensive function that the trauma-dissociation model attributes to dissociation. Interestingly, there are other studies that found little or no evidence for the amnesic power of dissociation. For example, Wessel, Merckelbach, Kessels and Horselenberg (2001) reported that high and low dissociators do not differ with regard to autobiographical memory specificity. In that study, individuals high on dissociation did not react with more overgeneral memories to positive or negative cue-words than did individuals low on dissociation. Furthermore, Kindt and Van den Hout (in press) found that individuals with high selfreports of peri-traumatic dissociation (i.e., dissociation during an emotional event) did not show evidence for fragmented memory of an emotional film.

On the other hand, compared to low DES individuals, high DES participants did produce more commissions during free recall. Although this observation is consistent with a number of previous studies documenting a robust connection between dissociation and pseudomemories (e.g., Clancy, Schacter, McNally, \& Pitman, 2000; Merckelbach, Muris, Rassin \& Horselenberg, 2000), it is not fantasy proneness that accounts for this relationship. Interestingly, Merckelbach, Horselenberg and Schmidt (2002) pointed out that dissociation has two prominent correlates: fantasy proneness and absentmindedness. It might well be the case that absentmindedness rather than fantasy proneness is the crucial mediator in the connection between dissociation and memory commissions. Evidence for this comes from a study in which it was found that the heightened suggestibility levels of high dissociators were partially dependent on absentmindedness (Merckelbach, Muris, Rassin \& Horselenberg, 2000). Clearly, this possibility warrants further study.

Several limitations of the current study deserve comment. To begin with, although the subjective impact of the story came close to that reported in previous studies (e.g., Muris et al., 1992), one might question whether it was powerful enough to elicit intense emotions. On a related note, one might doubt the personal significance of the emotional event. This could be accomplished by comparing recall for emotional events which occurred outside the lab with objective facts (e.g., comparing crime victims' accounts with police reports). A methodological limitation is that we used one type op emotional stimuli, namely an auditory story. Future studies should use different types of emotional stimuli and examine whether the same results are obtained. Meanwhile, delay between stimuli exposure and recall should be manipulated or participants should be tested over time to increase ecological validity. Another issue is that we did not evaluate to what extent our participants had a traumatic background. One could argue that the defensive function of dissociation only shows up in people who have been repeatedly traumatized. Thus, it is conceivable that there are two pathways to dissociation: a benign fantasy proneness route that is not necessarily connected to defensive coping and a traumatogenic pathway that is intimately linked to defence. In order to explore this possibility, studies comparing traumatized and nontraumatized dissociators on memory and arousal would be required.

To sum up, then, the current findings demonstrate that at least in an undergraduate sample and 
with moderately strong emotional material, dissociation does not seem to serve a defensive function. On the other hand, it is related to memory commissions.

\section{References}

Apitzsch, H. (1996). Trauma and dissociation in refugee patients. Nordic Journal of Psychiatry, 50, 333-336.

Bernstein, E. M., \& Putnam, F. W. (1986). Development, reliability, and validity of a dissociation scale. Journal of Nervous and Mental Disease, 174, 727-735.

Clancy, S. A., Schacter, D., McNally, R. J., \& Pitman, R. K. (2000). False recognition in women reporting recovered memories of sexual abuse. Psychological Science, 11, 26-31.

Dunning, D., \& Stern, L. B. (1992). Examining the generality of eyewitness hypermnesia: A close look at time delay and question type. Applied Cognitive Psychology, 6, 643-657.

Gershuny, B. S., \& Thayer, J. F. (1999). Relation among psychological trauma, dissociative phenomena, and traumarelated distress: A review and integration. Clinical Psychology Review, 19, 631-657.

Gudjonsson, G. H., \& Clare, I. C. H. (1995). The relationship between confabulation and intellectual ability, memory, interrogative suggestibility and acquiescence. Personality and Individual Differences, 19, 333-338.

Heaps, C., \& Nash, M. (1999). Individual differences in imagination inflation. Psychonomic Bulletin and Review, 6, 313-318.

Holtgraves, T., \& Stockdale, G. (1997). The assessment of dissociative experiences in a non-clinical population: reliability, validity, and factor structure of the dissociative experiences scale. Personality and Individual Differences, 22, 699-706.

Kindt, M., \& Van den Hout, M. (in press). Dissociation and memory fragmentation: experimental effects on metamemory but not on actual memory performance. Behaviour Research and Therapy.

Loewenstein, R. J. (1991). Psychogenic amnesia and psychogenic fugue: A comprehensive review. In A. Tasman, \& S. M. Goldfinger (Eds.), American Psychiatric Press review of psychiatry (vol. 10 pp. 189-222). Washington, DC: American Psychiatric Press.

Merckelbach, H., Horselenberg, R., \& Muris, P. (2001). The Creative Experience Questionnaire (CEQ): A brief selfreport measure of fantasy proneness. Personality and Individual Differences, 31, 987-995.

Merckelbach, H., Horselenberg, R., \& Schmidt, H. (2002). Modelling the connection between self-reported trauma and dissociation in a student population. Personality and Individual Differences, 32, 695-705.

Merckelbach, H., \& Muris, P. (2001). The causal link between self-reported trauma and dossociation: A critical review. Behaviour Research and Therapy, 39, 245-254.

Merckelbach, H., Muris, P., \& Rassin, E. (1999). Fantasy proneness and cognitive failures as correlates of dissociative experiences. Personality and Individual Differences, 26, 961-967.

Merckelbach, H., Muris, P., Rassin, E., \& Horselenberg, R. (2000). Dissociative experiences and interrogative suggestibility in college students. Personality and Individual Differences, 29, 1133-1140.

Muris, P., Merckelbach, H., Van den Hout, M., \& De Jong, P. (1992). Case histories and shorter communications. Behaviour Research and Therapy, 30, 639-642.

Pekala, R. J., Kumar, V. K., Ainslie, G., Elliott, N. C., Mullen, K. J., Salinger, M. M., \& Masten, E. (1999/2000). Dissociation as a function of child abuse and fantasy proneness in a substance abuse population. Imagination, Cognition, and Personality, 19, 105-129.

Porter, S., Birt, A. R., Yuille, J. C., \& Lehman, D. R. (2000). Negotiating false memories: Interviewer and rememberer characteristics relate to memory distortions. Psychological Science, 11, 507-510.

Rauschenberg, S. L., \& Lynn, S. J. (1995). Fantasy proneness, DSM-III-r axis I psychopathology, and dissociation. Journal of Abnormal Psychology, 104, 373-380.

Ross, C. A., Joshi, S., \& Currie, R. (1991). Dissociative experiences in the general population: A factor analysis. Hospital and Community Psychiatry, 42, 297-301.

Silva, C. E., \& Kirsch, I. (1992). Interpretive sets, expectancy, fantasy proneness, and dissociation as predictors of hypnotic response. Journal of Personality and Social Psychology, 63, 847-856. 
Van der Kolk, B. A., \& Van der Hart, O. (1989). Pierre Janet and the breakdown of adaptation in psychological trauma. American Journal of Psychiatry, 146 (1530-154).

Wenzlaff, R. M., Wegner, D. M., \& Roper, D. W. (1988). Depression and mental control: The resurgence of unwanted negative thoughts. Journal of Personality and Social Psychology, 55, 882-892.

Wessel, I., Merckelbach, H., Kessels, C., \& Horselenberg, R. (2001). Dissociation and autobiographical memory specificity. Clinical Psychology \& Psychotherapy, 8, 411-415.

Wilson, S. C., \& Barber, T. X. (1983). Fantasy-prone personality: Implications for understanding imagery, hypnosis, and parapsychological phenomena. In A. Sheikh (Ed.), Imagery: current theory, research, and application (pp. 340387). New York: Wiley.

Winograd, E., Peluso, J., \& Glover, T. A. (1998). Individual differences in susceptibility to memory illusions. Applied Cognitive Psychology, 12, S5-S27. 